\title{
PENDEKATAN LIFE SKILL BERBASIS LESSON STUDY PADA MATA KULIAH STATISTIK INFERENSIAL
}

\author{
Januar Kustiandi ${ }^{1}$, Rizza Megasari ${ }^{2}$ Rizky Dwi Putri $^{3}$ \\ 1. Economic Education Program, Faculty of Economics, State University Malang \\ 2. Economic Education Program, Faculty of Economics, State University Malang \\ 3. Economic Education Program, Faculty of Economics, State University Malang \\ januar.kustiandi.fe@um.ac.id, rizza.megasari.fe@um.ac.id, rizky.dwi.fe@um.ac.id
}

\begin{abstract}
Inferential statistics require students to understand and be skilled in the advanced application of descriptive statistics in the parametric and non parametric drawings required by students to achieve competence in the formulation of models, the selection of analytical techniques and conclusions as well as the interpretation of the sample statistical test results within the scope of the development economy. The problems faced are the limited knowledge of students both in the level of concept and the direct implementation of statistical materials. Another problem found in the learning process is the lack of understanding of students both individually and in groups towards the use of statistical tools to suit the needs of the analysis. The objectives of this research are (1) to know the implementation of life skill approach based on lesson study, (2) to know the increase of positive character of student of inferential statistic through life skill approach based on Lesson Study. This research uses type of action research based on lesson study with qualitative descriptive approach. The research procedure is carried out for two cycles. Each cycle is carried out on a single subject to know the results that have been achieved by the research subject as a basis for improvement in the next cycle. Each cycle consists of three stages: plan, do, see. Based on of research, the implementation of life skill approach based on lesson study can be implemented well and able to improve the positive character of student.
\end{abstract}

Keywords: Lesson Study, Life Skill Approach

History of Article:

Received: (31 January 2017), Accepted :(19 February 2017), Publised: (15 March 2017)

\section{Citation:}

Kustiandi, Januar ; Megasari, Rizza \& Rizky Dwi Putri (2017) Pengaruh Pendekatan Life Skill Berbasis Lesson Study Pada Mata Kuliah Statistik Inferensial. [The Influence of Life Skill Approach Based on Lesson Study In Inferential Statistics Course]. Jurnal Pendidikan Ekonomi, 10(1), 60-65

(C) Universitas Negeri Malang 


\section{PENDAHULUAN}

Lesson study muncul sebagai salah satu alternatif yang berguna untuk mengatasi masalah praktik pembelajaran yang selama ini dipandang kurang efektif. Sebagaimana diungkapkan oleh Kusuma (2010) Sekarang ini masih banyak praktik pembelajaran di Indonesia yang cenderung melakukan pembelajaran secara konvensional. Praktik pembelajaran konvesional semacam ini lebih cenderung menekankan pada bagaimana dosen mengajar (teachercentered) dari pada bagaimana mahasiswa belajar (student-centered), dan secara keseluruhan hasilnya tidak banyak memberikan kontribusi bagi peningkatan mutu proses dan hasil pembelajaran mahasiswa. Dalam hal ini, Lesson Study dapat dijadikan sebagai salah satu alternatif guna mendorong terjadinya perubahan dalam praktik pembelajaran di Indonesia menuju ke arah yang jauh lebih efektif. Seperti dikatakan oleh Lewis (2002) pembelajaran yang berbasis pada lesson study perlu dilakukan karena beberapa alasan antara lain lesson study merupakan suatu cara efektif yang dapat meningkatkan kualitas pembelajaran yang dilakukan dosen dan aktivitas belajar mahasiswa

Lesson study merupakan kajian pembelajaran yang dilakukan oleh sesama dosen/dosen dalam kegiatan kelompok kerja dosen/dosen di suatu sekolah/universitas atau pun suatu tempat. Kajian pembelajaran yang dilakukan akan sangat berguna untuk menemukan nilai-nilai positif atau praktif terbaik (best practices) dari pembelajaran yang dapat diambil, yang kemudian dapat dipertahankan dan ditularkan kepada dosen-dosen yang lain. Selain itu, yang tidak kalah pentingnya tentu saja adalah untuk menemukan kelemahan-kelemahan atau bahkan kesalahan-kesalahan yang perlu diperbaiki atau untuk tidak dilakukan lagi oleh dosen itu atau dosen-dosen yang lain. Dengan kata lain, lesson study merupakan upaya terencana dan berkelanjutan untuk melakukan kajian terhadap proses belajar mengajar seorang dosen, untuk kepentingan perbaikan atau peningkatan efektivitas pembelajaran bagi dosen itu, yang secara kolegial bermanfaat untuk kepentingan perbaikan dan peningkatan efektivitas pembelajaran bagi dosen-dosen yang lain di sekolah atau di lingkungannya. Sesuai dengan Rusman (2010: p.384) Lesson Study merupakan kegiatan yang dapat mendorong terbentuknya sebuah komunitas belajar (learning society) yang secara konsisten dan sistematis melakukan perbaikan diri, baik pada tataran individual maupun manajerial.

Mata kuliah Statistik Inferensial sengaja dipilih karena mata kuliah ini merupakan mata kuliah yang dibutuhkan dalam pemilihan metode dan alat penelitian untuk menganalisis permasalahan penelitian, dan juga merupakan mata kuliah untuk mempersiapkan mahasiswa untuk belajar di mata kuliah pada semester lanjut meliputi ekonometrika, metodologi penelitian ekonomi dan bisnis serta ekonomi kuantitatif termasuk mendukung mahasiswa dalam penyelesaian tugas akhir nanti. Mata kuliah ini juga diharapkan dapat mengasah kemampuan hard-skills aupun soft-skills yang sangat vital dimiliki oleh mahasiswa. Berbagai keterampilan yang termasuk dalam kategori hard-skills dapat dideskripsikan sebagai keterampilan dalam memilih alat dan metode yang sesuai dengan permasalahan penelitian. Sedangkan dalam kawasan soft-skills, mahasiswa diharapkan kompeten dalam menyampaikan alasan pemilihan alat dan metode 
penelitian dan melatih keterampilan untuk bekerja sama dengan pihak lain, baik eksternal (stakeholders) maupun internal (antar mahasiswa).

Pada Pada penelitian ini, peneliti menerapkan pendekatan life skills. Pada dasarnya pendidikan life skills adalah pendidikan yang memberikan bekal dasar dan latihan yang dilakukan secara benar kepada mahasiswa tentang nilai-nilai kehidupan yang dibutuhkan dan berguna bagi perkembangan kehidupan mahasiswa. Dengan demikian pendidikan life skills harus dapat merefleksikan kehidupan nyata dalam proses pengajaran agar mahasiswa memperoleh kecakapan hidup tersebut, sehingga mahasiswa siap untuk hidup di tengah-tengah masyarakat.

Tujuan dari penelitian ini adalah mengetahui penerapan pendekatan life skill berbasis Lesson study pada mata kuliah statistik inferensial Off $\mathrm{N}$ prodi $\mathrm{S} 1$ Pendidikan Ekonomi Universitas Negeri Malang Angkatan 2014. Manfaat dari penelitian ini adalah mempelajari kelebihan dan kekurangan dari pendekatan life skills berbasis Lesson study jika diaplikasikan dalam pembelajaran. Apabila terdapat kekurangan maka dapat disempurnakan pada pengalaman-pengalaman selanjutnya.

\section{METODE PENELITIAN}

Jenis Penelitian ini adalah Penelitian Tindakan Kelas (PTK) berbasis LS (Lesson Study), Penelitian Tindakan kelas (PTK) merupakan penelitian yang bersifat reflektif dengan melakukan tindakan-tindakan tertentu agar dapat memperbaiki atau meningkatkan praktik-praktik pembelajaran di kelas lebih profesional (Suroso, 2007:20). Pendekatan penelitian berupa deskriptif kualitatif. Setiap pertemuan dalam PTK tersebut dilaksanakan dalam siklus LS dalam arti melalui tahapan plan (perencanaan bersama tim LS), do (pelaksanaan dilakukan dosen model dengan diobserveri oleh tim LS), dan see (refleksi bersama tim LS)

\section{Kehadiran dan Peran peneliti di Lapangan}

Kehadiran peneliti di lapangan menjadi dosen model yang akan memberikan pengajaran di kelas tersebut sebanyak 5 kali pertemuan. Peneliti mencoba untuk mengobati permasalahan yang ditemukan dalam suatu penelitian

\section{Kancah Penelitian}

Penelitian dilakukan di kelas off N Matakuliah Statistik Inferensial, Prodi S1 Pendidikan Ekonomi, Fakultas Ekonomi. Kegiatan penelitian dilakukan pada hari Kamis Jam ke 4-6 sejak tanggal 9 September sampai 7 Oktober 2016.

\section{Subyek Penelitian}

Subyek penelitian ini adalah mahasiswa UM off $\mathrm{N}$ prodi $\mathrm{S} 1$ Pendidikan Ekonomi yang sedang menempuh mata kuliah Statistik Inferensial semester 5. Jumlah mahasiswa sebanyak 40 orang.

\section{Instrumen Penelitian}

Instrumen penelitian meliputi perangkat pembelajaran dan instrumen pengumpulan data. Perangkat pembelajaran meliputi meliputi SAP, Lembar Kegiatan Mahasiswa. Instrumen pengumpulan data yang diperlukan pada penelitian ini meliputi wawancara dan catatan lapangan untuk memperoleh data awal, lembar keterlaksanaan pembelajaran simulasi LS oleh dosen model, catatan lapangan, 
lembar observasi keterlaksanaan keterampilan kolaboratif mahasiswa dengan aspek yang akan dicapai adalah aspek bekerja secara produktif, aspek menghargai, aspek berkompromi dan aspek saling berkontribusi dan berbagi dengan penuh kejujuran, disiplin dan tanggung jawab, instrumen lain yaitu soal post test siklus I, II, dan III untuk mengetahui tingkat hasil belajar kognitif yang mana soal diberikan dalam tingkatan kognitif tingkat tinggi $\mathrm{C} 3-\mathrm{C} 5$, kemudian lembar istrumen plan, do, see untuk penilaian keterlaksanaan LS.

Teknik Analisis Data

Teknik analisis data untuk uji Data pendekatan life skills siswa diperoleh melalui lembar observasi siswa selama kegiatan pembelajaran berlangsung pada siklus I, siklus II, dan siklus III.

\section{HASIL \& PEMBAHASAN}

\section{Pendekatan Life Skill berbasis Lesson Study pada Mata Kuliah Statistik Inferensial}

Pelaksanaan pendekatan Life Skill berbasis LS dilaksanakan tiga siklus. Pada siklus I, pembelajaran sudah dilaksanakan dengan baik oleh dosen model. Namun, terdapat permasalahan bahwa dosen model harus menjelaskan ulang materi Statistik Deskriptif yang menjadi dasar dan prasyarat untuk menempuh Statistik Inferensial karena mahasiswa lupa dengan materi awal yang harus dipahami sebelumnya. Sehingga pada pelaksanaan siklus I, dosen model harus melakukan modifikasi sesuai dengan permasalahan kelas untuk menanamkan kembali pemahaman dasar tentang statistika kepada mahasiswa.

Kekurangan yang didapatkan diperbaiki pada kegiatan plan pada siklus II di mana dosen model yang merancang ulang kegiatan pembelajarannya secara mandiri, kemudian mendiskusikannya dengan tim LS untuk mendapatkan kritikan dan masukan sampai mendapatkan perencanaan pembelajaran yang lebih baik. Hasil refleksi dari siklus II, diketahui bahwa perlu disesuaikan antara model pembelajaran dan kondisi kelas, mengingat dalam pelaksanaan siklus I juga diketahui permasalahan lain bahwa mahasiswa mengalami kesulitan karena statistik berhubungan dengan matematika, sedangkan image matematika untuk mahasiswa adalah sulit.

Setelah itu, dosen model mencoba untuk memperbaiki rencana pembelajaran sesuai dengan hasil kegiatan plan yang dilakukan. Hasil perbaikan tersebut akan diimplementasikan pada kegiatan do (tindakan) pada pertemuan ketiga. Pada kegiatan ini diobservasi oleh dua observer (teman sejawat), satu observer dari dosen pengampu matakuliah SBM, dan satu observer dari dosen pengampu Matematika Ekonomi. Setelah kegiatan do selesai maka dilakukan kegiatan see (refleksi) untuk melihat kekurangan dan kelebihan dosen model dalam pelaksanaan do di siklus II.

kekurangan yang ada pada siklus II di mana model pembelajaran dengan pendekatan life skill yang dilakukan oleh dosen model masih belum mampu memberikan kemudahan bagi mahasiswa untuk melakukan pemilihan dan penggunaan alat analisis yang benar sesuai dengan masalah dan data yang diberikan. Hal ini kemudian diperbaiki oleh dosen model dan didiskusikan kembali pada tahap plan pada siklus III. Pada pelaksanaan LS di siklus III dengan pendekatan life skill dan perbaikan pada model pembelajaran, diketahui bahwa dosen model mampu memberikan pemahaman pada mahasiswa di mata kuliah Statistik Inferensial dan mahasiswa mampu mengaplikasikan teori serta bisa 
memilih alat dan metode sesuai dengan masalah dan data penelitian yang diperoleh dalam ranah kuantitatif.

Pelaksanaan pembelajaran dengan pendekatan life skill yang dikemas dalam bentuk Lesson Study memberikan situasi baru bagi dosen dan mahasiswa. Dosen yang biasanya mengajar seorang diri dalam kegiatan Lesson Study ditemani oleh keempat observer. Menurut Susilo (2012:p. 13) PTK dilaksanakan berbasis Lesson Study dalam rangka terutama agar dapat memperkuat pelaksanaan PTK yang merupakan proses yang dinamis di mana ada empat tahap yaitu 1) perencanaan tindakan, 2) pelaksanaan atau implementasi tindakan, observasi dan asesmen 3) análisis hasil observasi dan asesmen dilanjutkan dengan interpretasi, 4) refleksi. Setiap pertemuan dalam PTK tersebut dilaksanakan dalam siklus LS dalam arti melalui tahapan plan, do, dan see.

\section{Peningkatan pendidikan life skills Mahasiswa Melalui Lesson Study}

Life skills adalah pendidikan yang memberikan kecakapan personal, kecakapan sosial, kecakapan intelektual dan kecakapan untuk bekerja, berusaha dan hidup mandiri. Adapun orientasi life skills yakni membangun sikap kemandirian untuk mendapatkan ketrampilan sebagai bekal untuk bekerja dan mengembangkan diri (skilled orientation). Indikator-indikator yang terkandung dalam life skills tersebut secara konseptual dikelompokkan : (1) Kecakapan mengenal diri (self awarness) atau sering juga disebut kemampuan personal (personal skills) (2) Kecakapan berfikir rasional (thinking skills) atau kecakapan akademik (akademik skills) (3) Kecakapan sosial (social skills) (4) Kecakapan vokasional (vocational skills) sering juga disebut dengan keterampilan kejuruan artinya keterampilan yang dikaitkan dengan bidang pekerjaan tertentu dan bersifat spesifik (spesifik skills) atau keterampilan teknis (technical skills) (Ditjen PLS, Direktorat Tenaga Teknis, 2003). Berdasarkan hasil penelitian terjadi peningkatan keterampilan life skills mahasiswa dari siklus III dibandingkan dengan siklus I dan siklus II sesuai dengan indikator tersebut.

Beberapa keterbatasan dalam pelaksanaan Lesson Study ini adalah mengenai waktu pelaksanaan Lesson Study yang hanya berlangsung selama (dua) bulan berkontribusi terhadap tidak maksimalnya penyelenggaraan Lesson Study secara maksimal. Permasalahan yang kedua berkenaan dengan clazz size (ukuran kelas) yang cukup besar. Sehingga kadang menyulitkan observer untuk mengamati pelaksanaan dalam proses pembelajaran.

\section{KESIMPULAN}

Berdasarkan pelaksanaan pembelajaran yang telah dilakukan, maka dapat disimpulkan bahwa:

1. Model pendekatan life skills dirasa sudah efektif dalam pelaksanaan mata kuliah yang bersangkutan karena karakteristik mata kuliah sesuai dengan indikatorindikator yang harus dikuasai mahasiswa.

2. Kegiatan lesson study yang diselenggarakan pada umumnya berjalan lancar, namun demikian beberapa kendala mengangkut waktu dan class size menjadikan permasalahan tersendiri yang harus dihadapi.

3. Kegiatan lesson study yang dikembangkan bisa disimpulkan mampu memberikan dampak yang signifikan terhadap keberlangsungan proses pembelajaran di lingkungan fakultas. 
Melalui pelaksanaan Lesson Study dapat disarankan antara lain sebagai berikut:

1. Perlunya alokasi waktu yang memadai sesuai kebutuhan masing - masing mata kuliah

2. Perlunya pengaturan class size agar lebih kondusif dalam proses pembelajaran sehingga dapat berjalan lebih efektif dan kondusif

3. Perlunya ada kegiatan workshop sebagai tidak lanjut hasil - hasil penelitian

\section{DAFTAR RUJUKAN}

Ditjen PLS (2003). Program Life Skills Melalui Pendekatan Broad Based Education (BBE). Jakarta : Direktorat Tenaga Teknis Depdiknas.

Kusuma, Ersanggono Dkk. (2010) Pengembangan Bahan Ajar Kimia Berorientasi Chemo-Entrepreneurship untuk Meningkatkan Hasil Belajar dan Life Skill Mahasiwa. Jurnal Inovasi Pendidikan Kimia, 4 (1), 544-551.

Lewis, C.C (2002) Lesson study: A Handbook of Teacher-Led Instructional Change. Philadelphia: Reseach For better School .Inc.

Rusman (2010) Model-model Pembelajaran Mengembangkan Profesionalisme

Guru, Jakarta: PT Raja Grafindo.

Suroso (2007) Panduan Menulis Artikel dan Jurnal. Yogyakarta: Paparaton.

Susilo, Herawati (2012) Lesson Study dalam Bentuk Penelitian Tindakan Kelas (PTK) Sebagai Sarana Peningkatan Kualitas Pembelajaran. Makalah disajikan dalam Seminar Pendidikan Biologi dengan tema "Lesson Study sebagai Peningkatan Kualitas Pengajaran"di Gedung Soetarjo Universitas Jember 